\title{
Mówi we mnie Się
}

Marta M. Kania 


\section{Mówi we mnie Się}

Marta M. Kania

TEKSTY DRUGIE 2017, NR 3, S. 321-331

DOI: $10.18318 /$ td.2017.3.19
Przygotowanie tego tekstu było możliwe dzięki grantowi badawczemu „Perspektywy awatara. O filozoficznych i estetycznych możliwościach gier komputerowych", finansowanemu ze środków Narodowego Centrum Nauki na podstawie decyzji numer DEC-2013/og/D/ HS1/00424.
Najpierw jest faktyczne jestestwo w odkrytym przez przeciętność wspólnym świecie.

Najpierw jestem nie «ja» w sensie własnego Siebie, lecz inni w postaci Się.

Od jego strony i jako ono staję się «sobie» po raz pierwszy «dany».

Jestestwo jest najpierw Się i zwykle nim pozostaje. ${ }^{1}$

est początek lat 70. XX wieku. Angela Burnes, czarnoskóra Amerykanka, dzięki studiom próbowała uciec przed typowym losem kobiet z Baltimore - uciec przed Się determinującym odpowiedniość społecznej pozycji i roli, Się wyznaczającym los. Jednak utknęła w Anchurii, fikcyjnym kraju położonym w Ameryce Łacińskiej, z powodu przewrotu wojskowego, jaki rozpętał się podczas jej wizyty. Tutaj zaś, w obcym kraju, gdzie ludzie mówią w nieznanym jej języku, musiała podjąć się roli, przed
Marta M. Kania -

doktor filozofii. Zajmuje się twórczymi działaniami wyobraźni, poruszając się po pograniczach filozofii egzystencjalnej, estetyki i groznawstwa. Współpracuje z Dolnośląską Szkołą Wyższą. Autorka książki Żywioły wyobraźni. O wyobrażaniu i przeobrażaniu (2014). Kontakt: martamatyldakania@gmail.com

1 M. Heidegger Bycie i czas, przeł. B. Baran, PWN, Warszawa 1994, s. 184 [129]. 
którą tak bardzo chciała uciec. „Pięć lat w Harrison College, żyjąc z napiwków i tego, co udało się zaoszczędzić cioci Anicie. Pięć lat, żeby dostać kawałek papieru potwierdzający, że jestem inżynierem. Potrafię też posprzątać dom tego człowieka"2.

Grając w grę Sunset ${ }^{3}$, jako Angela kieruję się do windy. Moje obowiązki i rola w świecie gry stają się jasne, gdy postrzegam Angelę jako siebie. Wykonując zadania wyszczególnione na liście przyklejonej w windzie, wkraczam w sytuację rozgrywki, „staję się” Angelą Burnes: jej rola wyznacza moje powinności, a zadania - te wykonane, oczekujące na wykonanie i te zaniedbane - determinują moją pozycję w świecie gry. Monologi i komentarze odnoszą się do moich działań, wskazując, jak w świecie gry „powinno się" je wykonywać. Sprawiają, że kwestia obowiązków domowych nabiera ponadindywidualnego znaczenia. Słowa Angeli sprawiają, że mówi we mnie Się.

Prowadzone przez Angelę monologi określają „sytuację rozgrywki”, pozwalają mi rozumieć siebie-awatara jako moje własne usytuowanie w świecie gry, jestem tutaj „najpierw Się”, „nie «ja» w sensie własnego Siebie"4.

Angela Burnes przegląda się w lustrze. Odbija się w tafli szklanych drzwi w apartamencie należącym do Gabriela Ortegi. Słowa Angeli dookreślają także jej usytuowanie w świecie gry, nadają znaczenie, wtórując echem: „Jestem sama w apartamencie. To nie jest mój dom, ale ścianom i oknom nie robi to różnicy. I nie ma tu nikogo innego, kto by mnie widział. Mogę robić, na co mam ochotę, ale powstrzymuję się. Siadając na biurku pana Ortegi, dotykając jego rzeczy, czuję się ambiwalentnie"

Za chwilę zajdzie słońce, co oznacza, że dobiega końca czas przeznaczony na wykonanie zleconych mi przez tajemniczego pracodawcę zadań. Monologi Angeli sprawiają, że odrywam się od rozgrywki i podejmuję refleksję estetyczną z pozycji mnie-awatara: skupiam się na jej uwarunkowaniach, na estetycznych cechach otoczenia postrzeganego z jej perspektywy oraz dystansie, jaki pojawia się w odniesieniu do pozycji zajmowanej podczas rozgrywki. Coraz wyraźniej ujawnia się bowiem i narasta d y s ta n s między bohaterką

2 Jeśli nie zaznaczono inaczej, przekłady z angielskiego przygotowała autorka. Tale of Tales Sunset, 2015 .

3 Tamże.

4 M. Heidegger Bycie i czas, s. 184 [129].

5 Tale of Tales Sunset. 
i jej wiedzą a mną-graczką, która odnosi się do tego indywidualnego sposobu usytuowania w obrębie świata gry. Wbrew słowom Angeli nie mam zamiaru usiąść na biurku Gabriela Ortegi, a przebywając w jego apartamencie, nie powstrzymuję się przed robieniem tego, na co mam ochotę - bez zezwolenia rozpakowuję zamknięte jeszcze w przeprowadzkowych kartonach bibeloty, zostawiam odkręcony kran. Opuszczam apartament. Angela jest bohaterką, częścią świata gry.

Jak z perspektywy gry jako świata, w którym jestem zanurzona, grając w grę̨ ${ }^{6}$ mogę opisać tę dwoistą relację między monologującą postacią a mną-graczką, naprzemiennie postrzegającą awatara jako siebie i jako element świata gry?? Spróbuję odpowiedzieć na te pytania z perspektywy filozofii egzystencjalnej, interpretując Sunset, grę, która - także dzięki swym brakom - w ciekawy sposób ujawnia rozdźwięk między graczką i awatarem, wewnątrzgrowymi powinnościami a przyjemnością rozgrywki.

Pierwsza kwestia, na jakiej się skupię, to pojawiający się przy próbie opisu doświadczenia postaci gracza dystans określający relację między graczką postrzegającą siebie jako „ja”, bycie-w-grze doświadczane za pośrednictwem

6 Por. O.T. Leino Understanding games as played: sketch for a first-person perspective for computer game analysis, referat wygłoszony na konferencji The Philosophy of Computer Games Conference, Oslo 2009. O.T. Leino Emotions in play: on the constitution of emotion in solitary computer game play, praca doktorska obroniona na: IT University of Copenhagen, Denmark, 2010, s. 133-134.

7 Wielowymiarowy model opisujący "ja” w świecie gry z perspektywy fenomenologicznej stworzył Daniel Vella. O ile jednak Vella określa sposoby ustanawiania pozycji gracza dzięki awatarowi i postaci podczas rozgrywki, ja postaram się wskazać miejsca, w których między graczką a protagonistką (awatarem i postacią) narasta dystans, dzięki któremu egzystencjalna sytuacja rozgrywki zaczyna być postrzegana jako sytuacja estetyczna. Funkcja mówiącego we mnie-awatarze Się, jest przez Vellę określana jako "subiektywna relacja do Innego", która oznacza możliwość "patrzenia przez awatara” jako Innego. Tutaj zaś, zamiast zakładać możliwość spojrzenia na świat gry z pozycji Innego, ujmuję tę zmianę perspektywy jako doświadczenie odmiennych uwarunkowań własnej percepcji i rozumienia sytuacji, które nie są jednak tożsame z wejściem w rolę postaci. D. Vella"It's a-me/Mario": playing as a ludic character, ed. by G.N. Yannakakis, E. Aarseth, K. Jørgensen, J.C. Lester, w: Proceedings of the 8th International Conference on the Foundations of Digital Games (FDG 2013), Society for the Advancement of the Science of Digital Games, Chania 2013; D. Vella Player and figure: an analysis of a scene in Kentucky Route Zero, w: Proceedings of Nordic DiGRA 2014 Conference, Visby 2014; D. Vella The ludic subject and the ludic self: analyzing the 'I-in-the-gameworld', praca doktorska obroniona w: Center for Computer Games Research, IT University of Copenhagen, Denmark 2015.

8 Por. M. Heidegger Bycie i czas. J.-P. Sartre Byt i nicość: zarys ontologii fenomenologicznej, przeł. J. Kiełbasa, P. Mróz, Zielona Sowa, Kraków 2007. O.T. Leino, S. Möring A sketch for an existential ludology, referat wygłoszony na konferencji Central and Eastern European Games Conference, Uniwersytet Jagielloński, Kraków, 24.10.2015. 
awatara i dzięki niemu usytuowane, a protagonistką wygłaszającą monologi i określającą siebie własnym spojrzeniem? .

O wspólnym zdystansowanym byciu, które - jak sądzę - stanowi ciekawą podstawę interpretacji tej relacji, pisze Martin Heidegger: „W zatroskaniu o to, co się uchwyciło wspólnie z innymi, dla nich i przeciw nim, tkwi nieustanna troska o odróżnienie się od innych [podkr. aut.]: zarówno wtedy, gdy chce się tylko tę różnicę zniwelować, jak wtedy, gdy własne jestestwo - pozostające w tyle za innymi - chce ich dogonić, jak wreszcie wtedy, gdy mając przewagę nad innymi, pragnie utrzymywać ich w podległości. Wspólne bycie jest - w sposób dla niego samego skryty - niepokojone troską o ów dystans. Egzystencjalnie rzecz ujmując, ma ono charakter zdystansowania"10.

Sądzę, że również wspólne bycie graczki i awatara, moje i Angeli Burnes, jest rozpięte między tym, co dystans pogłębia i tym, co go zaciera; tym, co dzieje się wspólnie z postacią i przeciwko niej. W Sunset gra estetycznego dystansu rozwija się dzięki dialektyce pęknięć między treścią m o n o l o g ó w a światem dostępnym graczce, w a u d i o w i z u a l n y c h znakach odrębności postaci, a także w m e chanice sterowania zachowaniem awatara.

Przestrzeń ruchu graczki ograniczona jest do mieszkania Gabriela Ortegi. Tu też graczka "spotyka się" z awatarem, tylko tutaj może zacierać się dystans między "nią" i „mną": raz w tygodniu, tylko na godzinę poprzedzającą zachód słońca. Angela Burnes „żyje” zaś przez cały pozostały czas i o kluczowych dla fabuły wydarzeniach toczących się w Anchurii informuje mnie w swoich monologach. Każdy dzień pracy rozpoczyna od obszernego komentarza na ten temat: mówi o sytuacji politycznej i niepokojach na ulicach, rosnącym zagrożeniu i swoich obawach. Mówi, że apartament to „ukryte miejsce, w którym przez małą chwilę mogę udawać, że żadne z tych wydarzeń nie miało miejsca"11. W Sunset zwraca uwagę niedostępność świata, a zarazem jego obecność, nadobecność budująca przestrzeń opowieści.

Angeli nie zawsze łatwo jest dostać się do apartamentu, którym się zajmuje. Wojna domowa sprawia, że protagonistka raz po raz usprawiedliwia się przed sobą i przede mną-graczką - „Spóźniłam się! W drodze tutaj musiałam minąć tyle posterunków. Zabieram się do pracy”², albo „Znów spóźniona.

10 M. Heidegger Bycie i czas, s. 179-180 [125-127].

11 Tale of Tales Sunset.

12 Tamże. 
Na zewnątrz panuje gorączka. Wszędzie są żołnierze"13. Ja jednak spotykam się z nią dopiero w windzie, nie zobaczę w grze ani „zewnętrza”, ani żadnego strażnika wojskowego porządku.

O specyficznym „zacieśnieniu” świata będzie mi jednak przypominać panorama miasta rozpościerająca się z tarasu przynależącego do mieszkania Ortegi. Staje się ono widoczne także dzięki przebiegowi rozgrywki, która początkowo obejmuje całe, nieumeblowane jeszcze mieszkanie. Z biegiem czasu, podczas kolejnych tygodni jego zagospodarowywania, dostęp do przestrzeni apartamentu jest ograniczany - Angela może wejść tylko tam, gdzie ma do wykonania zadanie. W trzeciej, finalnej fazie gry będzie miała dostęp tylko do głównego hallu i jednego pokoju wybranego przez pracodawcę.

Wraz z narastaniem przestrzennych ograniczeń zmieniają się także tematy, jakie porusza Angela. Choć nie jest to zmiana linearna, można zauważyć stopniowe przesuwanie się akcentów w wypowiedziach protagonistki. Początkowo jej komentarze koncentrują się na sytuacji politycznej kraju i jej zdaniu na temat roli, jaką może bądź powinna odegrać w tych wydarzeniach. Później opowiada o swoim bracie, rewolucjoniście - ich wspólnym dzieciństwie i jego aktualnym losie. W końcu za pośrednictwem prowadzonych przez nią w windzie wewnętrznych monologów graczka przygląda się powstającej częściowo poprzez jej własne wybory - ambiwalentnej, potencjalnie romantycznej - relacji między bohaterką i jej pracodawcą.

Angela Burnes jednak najchętniej mówi o swoich uczuciach. Referując moment, gdy podczas sprzątania odkryła, że jej pracodawca jest zamieszany we współpracę z reżimem, mówi: „Nie mogłam nawet drgnąć, gdy przeczytałam dokumenty, które Ortega przyniósł do domu do podpisania. Stałam tam, z walącym sercem i płonącą twarzą. [...] Na początku czułam się źle, myszkując, ale gdy skończyłam czytać, wiedziałam że mój brat i jego przyjaciele rewolucjoniści muszą się o tym dowiedzieć”14. Gdy zaś angażuje się w działania wspierające opór wobec władzy, zauważa: „Czuję dziwną radość. To nie jest moja ojczyzna, ale robię coś sensownego"15.

We wszystkich wypowiedziach Angeli pobrzmiewa ton wyznania. Dzięki nim kształtu nabiera jej postać, wokół której skoncentrowany jest świat gry. Angela Burnes mówi o sobie, odbija się w lustrach, rzuca cień, jest silnie

\footnotetext{
13 Tamże.

14 Tamże.

15 Tamże.
} 
obecna zarówno jako wirtualna cielesność, jak i komentatorka. Jej monologi pełnią dwojaką funkcję - z jednej strony niwelują dystans, wprowadzając graczkę w zakamarki „duszy awatara”, pozwalają zapoznać się z wewnątrzgrowym Się. Z drugiej jednak strony to właśnie one ten dystans budują: pozwalają bowiem usłyszeć, jak we mnie-awatarze mówi „ona”, nie „ja”, jak wyłania się bohaterka obdarzona sprawczością, wobec której się dystansuję.

Zdystansowana „inność” Angeli Burnes zyskuje swój charakter, dookreśla się także dzięki wykorzystaniu specyficznych dla medium możliwości przyglądania się sobie. W prowadzonej z pierwszoosobowej perspektywy rozgrywce awatar - zwykle ukryty przed okiem graczki - staje się widoczny właśnie dzięki refleksom, cieniom, lustrzanym odbiciom.

Sprzyja temu modernistyczna architektura mieszkania, w którym toczy się gra. Inspirowane apartamentem Yves Saint-Laurenta ${ }^{16}$, pełne jest lśniących powierzchni i ogromnych przeszkleń. Analogicznie do poprzednich gier i prototypów duetu Tale of Tales ${ }^{17}$ awatar na chwilę pozostawiony sam sobie zaczyna zachowywać się w charakterystyczny sposób. To dziwne momenty, kiedy odbijająca się w lustrze postać wykonuje niekontrolowane przez graczkę gesty - unosi ręce, przygląda się sobie - podkreślając egzystencjalny dystans wobec graczki.

Jednak dialektyka dystansu zaznacza się najpełniej, gdy graczka może współdecydować o emocjonalnym - czułym bądź funkcjonalnym/operacyjnym - odniesieniu do listy zadań powierzonych Angeli. O ile monologi protagonistka wygłasza w pierwszej osobie, tutaj wypowiedź zmienia się $w$ polecenie wypowiadane w jej stronę. Sama forma językowa separuje mnie więc od Angeli, sytuuje obok niej - a względem przedmiotu bądź obowiązku. Poznając Angelę poprzez jej wypowiedzi, mogę teraz działać „wraz z nią” lub „przeciwko niej”: podporządkowywać wybory własnemu odczytaniu jej aktualnego nastroju czy stosunku do pracy. Albo też zwiększać dystans, zachowując się niezgodnie z jej wyrażanymi w monologach preferencjami: Angela uważa bowiem za dobre to, co proste, czułe, uczciwe. Bez względu na strategię działania, moje wybory dotyczące zachowania Angeli nie zmieniają charakteru postaci ani nie wpływają na kształt sytuacji w świecie gry, a jedynie na jej emocjonalny wyraz. To, że Angela ma określony c h a r a k t e r, że rozpoznaję coraz wyraźniej pe r s p e k ty w ę patrzenia, odczuwania, rozumienia

16 M. Samyn The tale of the tale of Sunset, 28.04.2015, http://tale-of-tales.com/Sunset/blog/index. php/2015/04/28/the-tale-of-the-tale-of-sunset/ (5.10.2016).

17 Tale of Tales The Path, 2009. Tale of Tales Fatale, 2009. Tale of Tales The Endless Forest, 2005. 
i wartościowania, determinuje znaczenie mojego postępowania w grze. Owo rozpoznanie sprawia, że zaczynam zachowywać się względem niej - tak jak w ujęciu filozofii egzystencjalnej jednostka zachowuje się zawsze względem $\mathrm{Się}^{18}$ - rozpoznając swoje z góry dane położenie. Mogę utwierdzać się w nim poprzez „upadanie"19 bądź „złą wiarę"20, sprawnie podporządkować się wymaganiom środowiska; albo zwiększać dystans, dążąc do autentycznego wyboru roli, jaką odgrywam ${ }^{21}$.

Odniesienie wewnętrznie rozdwojonej mnie-awatara do świata gry jest momentem ujawniania się egzystencjalnego znaczenia wewnątrzgrowego Się, w którym osadzam się stopniowo podczas eksploracji tego świata. Owo wewnątrzgrowe Się jest bowiem sposobem bycia-zdeterminowanym przez piętrzące się wokół zadania, obowiązki i spojrzenie innych, w którym „decydująca jest tylko dyskretna, od jestestwa jako współbycia niepostrzeżenie przejęta dominacja innych"22. Zmniejszając dystans między mną i Angelą - doświadczając awatara jako siebie, mnie-awatara - odbieram głos protagonistki już nie jako znak odrębnej egzystencji, lecz jako wyraziciela ponadindywidualnego porządku. Odczuwane jest ono jako presja czy forma bezosobowej władzy, obecnej, gdy „używamy sobie i bawimy się, tak jak się używa; czytamy, patrzymy i wydajemy sądy o literaturze i sztuce, tak jak się patrzy i sądzi" ${ }^{\prime 23}$.

Interpretowane z tej perspektywy komentarze Angeli Burnes - zarówno te samozwrotne, jak i te, które zarysowują egzystencjalne u s y t u o w a n i e gracza i samej postaci - określają sens świata gry jako z góry ukonstytuowany, lecz odmienny od sensu codziennego świata graczki. Egzystencjalne Się rozpoznaję w nim jako powinności, oczywistości, oraz szeroko rozumiane reguły, które poprzedzają indywidualny punkt widzenia i determinują moje rozumienie wewnątrzgrowego bycia. Heidegger stawia pytanie o Się, poszukując jego egzystencjalnego dookreślenia: „Kto zatem przejął bycie

18 Por. M. Heidegger Bycie i czas, s. 179 [125].

Tamże, s. 248 [175].

Por. J.-P. Sartre Byt i nicość: zarys ontologii fenomenologicznej, s. 80-81, 83-112. O.T. Leino Death loop as a feature, "Game studies. The international journal of computer game research" 2012 No. 2 (12).

Por. O.T. Leino Death loop as a feature; O.T. Leino, S. Möring A sketch for an existential ludology.

M. Heidegger Bycie i czas, s. 180 [126].

Tamże, s. 180 [126-127]. 
jako powszednie wspólne bycie?"24. Podążając tym tropem, zapytam: jak z perspektywy świata gry wyglądają relacje między mną-awatarem a tym, co w tym świecie poprzedza indywidualne nadawanie sensu; tym Się, które współkonstytuuje mnie w świecie gry, wyznaczając sytuację rozgrywki?

Z listy zawieszonej w windzie dowiaduję się o obowiązkach, względem których buduje się moja postać i które określają moje bycie w świecie gry słowem - „sytuację rozgrywki". Pracowniczą rutynę odzwierciedla mechanika gry, która staje się nudna, jak domowe obowiązki, gdy tylko zrozumiem jej nieskomplikowane działanie. Monologi dostarczają uzasadnienia, dlaczego wykonuję te prace i kim w świecie gry jestem dla innych. Jednak pęknięcie widoczne jest także między wewnątrzgrowym Się a postacią Angeli, która mówi: „oczekuje się ode mnie, żebym tu była, a równocześnie odbieram to jako transgresję"25, waham się „czego powinnam dotknąć, a co zignorować?"26.

W momencie jej wahania przejmuję inicjatywę. Współdziałając z Się działam jednak w „duchu powagi”: zachowuję się tak, jakbym była zdeterminowana przez rolę, którą raz wybrałam - jak kelner z egzystencjalnej powieści Sartre'a Drogi wolności, który redukuje siebie do bycia „tylko kelnerem" ${ }^{27}$. Wyznacznikiem ducha powagi nie jest jednak samo wykonywanie zadań, lecz patrzenie na świat i swoje w nim miejsce wyłącznie przez ich pryzmat. W grze jestem w tych momentach „tylko pomocą domową", która postrzega swoje działania jako zdeterminowane przez reguły: stan przedmiotów, wygląd wnętrz, potrzeby innych. Jestem wykonawczynią zadań wyszczególnionych na liście przyklejonej w windzie przez zleceniodawcę, a rytm moich działań wyznacza kurczący się czas do zachodu słońca.

Mechanika interakcji z przedmiotami jest w Sunset pomyślana na podobieństwo systemów dialogowych. Zdarza się, że graczka decyduje jedynie o tym, czy wejść w interakcję z przedmiotem (za pomocą klawisza „E” - „execute”, „wykonaj”). Zawsze może pozostawić niewykonane zadanie, nieprzekreśloną pozycję na liście obowiązków. Zwykle jednak wybór sposobu wykonania zadania skojarzony jest z klawiszami „Y” i „N”, jest wyborem między „tak” i „nie”, w których często pobrzmiewa także nuta wartościowania,

24 Tamże, s. $179[125]$.

M. Samyn Tale of Tales on the making of sunset: once upon a time, "Continue Play", 15.04.2015, http://www.continue-play.com/2015/04/15/tale-of-tales-on-the-making-of-sunset-onceupon-a-time/ (5.10.2016).

26 Tamże.

27 J.-P. Sartre Drogi wolności, przeł. J. Rogoziński, Zielona Sowa, Kraków 2005, s. 140. 
"dobrze" $i$ „źle”, tak jak we frazach: Y: „Czule wypoleruj srebra własnym oddechem” lub N: „Wypoleruj srebra standardowymi chemikaliami”28; albo Y: „Przygotuj delikatny, domowy posiłek z makaronu i sera” / N: „Przygotuj wyszukany posiłek z ostryg i kawioru"29.

Czego jednak dotyczy pytanie, na które - twierdząco bądź przecząco - odpowiada Angela, na które odpowiada graczka, wykonując swoje obowiązki? Na odpowiedź nakierowuje przede wszystkim konwencja sposobu wypełniania zadań. Ogranicza się ono bowiem do znalezienia właściwego miejsca i wybrania emocjonalnego „zabarwienia" przygotowania posiłku, odetkania odpływu, sposobu uporządkowania książek. Samą animację postaci Angeli wykonującej zadania zastępuje powtarzalna scena zachodu słońca w mieście, której towarzyszy wizerunek zegara sygnalizującego upływ czasu i dźwięk pogwizdywania przy pracy. To nawiązanie do konwencji lat'70, kiedy filmowe sceny erotyczne zastępowano kadrami przedstawiającymi krajobrazy, kwiaty czy zjawiska przyrodnicze.

Ta dialogowa mechanika powtarza się w sposobie interakcji z nieobecnym Gabrielem Ortega. Komentarze, które dopisuje Angela do notatek zostawianych przez gospodarza - na temat sprzętu muzycznego, szachów, dzieł sztuki - również przybierają emocjonalnie nacechowaną formę „Y” $\mathrm{i}, \mathrm{N}$, ,tak" $\mathrm{i}$ „nie”. Już w sam klawisz służący do interakcji wpisane jest zatem wartościowanie mojej wypowiedzi w odniesieniu do Angeli. A także ocena jej postępowania względem Gabriela oraz wykonywanego działania.

Wzbudzający opór dysonans przełamujący subtelną grę między byciem awatarem i byciem z awatarem, między świadomością bezosobowego Się a determinizmem, pojawia się pod koniec każdego dnia pracy Angeli. Słońce zachodzi nad San Bavon, a w jego świetle rozgrywa się krótki pojedynek, w którym stawką jest sprawczość w świecie gry. Punktualnie o 17:59 czasu oficjalnego Anchurii Angela Burnes wzdycha do siebie: „czas iść do domu”30. Jeśli nie zareaguję na jej sugestię, drzwi windy zasłonią mi pole widzenia niezależnie od miejsca, w którym aktualnie się znajduję. To Angela zdecydowała, że punktualnie wróci do domu.

Dystans skraca się jednak ostatniego wieczoru, kiedy decyzja o zakończeniu dnia pracy albo pozostaniu w mieszkaniu jest pozostawiona graczce.

28 Tale of Tales Sunset.

29 Tamże.

3o Tamże. 
Teraz to ja „staję się" Angelą Burnes, wydaje się, że to ja-awatar mogę podjąć decyzję. Dziś mam za zadanie przygotować kolację - mogę zadecydować o tym, czy przygotuję posiłek dla jednej czy dla dwóch osób. Drugi punkt listy zadań to „zostań aż wrócę”. Jednak, czy mogę sprzeciwić się wykonaniu tego zadania, pozostawić je na liście i - jak we wcześniejszych dniach - po prostu udać się do windy? Również dziś Angela przypomina mi, że mam już iść. Choć tym razem to nie postać decyduje o zakończeniu dnia pracy. Jeśli zostanę, obudzę się rano w sypialni Gabriela Ortegi. Jeśli zaś zdecyduję się opuścić apartament przed zachodem słońca... Również obudzę się w łóżku pracodawcy.

Mechanika rozgrywki sprawia, że zostaję wtłoczona w rolę Kopciuszka. Zaś postać Angeli, przekonanej o swoim krytycznym, aktywistycznym podejściu, popada w schemat - stereotypową rolę gosposi, która marzy o tym, by stać się godną miłości swego bogatego, wpływowego, przystojnego pracodawcy.

Angela Burnes szpieguje Gabriela Ortegę, podkrada informacje dotyczące militarnych operacji reżimu i przekazuje je swojemu bratu „i jego przyjaciołom rewolucjonistom"31. W jej język wplatają się rewolucyjne hasła, ideologiczne slogany i naiwne uzasadnienia: „Brak działania byłby gorszy niż niemoc. Jedyne, czego żałuję, to przelewanie krwi niewinnych; śmierć tych, którzy chcieli tylko żyć swoim życiem" ${ }^{\text {"32 }}$. Czy w innym miejscu „Ci, którzy czynią pokojową rewolucję niemożliwą, sprawiają, że siłowa rewolucja jest nieunikniona"33. Angela wygłasza również swoje zdanie o dziełach sztuki kolekcjonowanych przez Gabriela Ortegę - wypowiada się o obrazach i szachach, porównuje wartość sztuki z wartością ludzkiego życia. Szczególnie w trzeciej części gry stereotypizacja postaci nie daje o sobie zapomnieć, początkowe zainteresowanie Angelą Burnes zmienia się w zniecierpliwienie wywołane gadaniną, sloganowością, pustką postaci, która coraz wyraźniej redukuje się do Się świata gry powtarzanego w wypowiedziach i zachowaniach awatara.

Podsumowując, perspektywa postrzegania wewnątrzgrowego świata w „sytuacji rozgrywki” jest determinowana przez bezosobowe Się, kiedy dystans między mną i Angelą znika, gdy awatar to usytuowane w świecie gry „ja”. Gdy jednak podejmuję refleksję nad tym usytuowaniem w Sunset

Tamże.

Tamże.

Tamże. 
z perspektywy „sytuacji estetycznej”, raz po raz dostrzegam brak sprawczości, frustrujące potyczki z postacią Angeli Burnes - z jednej strony uosabiającej Się, zestaw reguł, przymusów i powinności, które mogę teraz nazwać i zinterpretować - z drugiej zaś prezentującej własną indywidualność, rozgrywając ją kosztem sprawczości graczki. Monologi protagonistki interpretowane z perspektywy sytuacji estetycznej pozwalają także dostrzec grę toczącą się między sprawczością postaci i moim wpływem na świat gry. Ujawnia ona usytuowanie mnie-awatara, podmiotu w świecie gry, na które składa się zarówno uwarunkowanie wykonywaną rolą, jak i aktywnie oddzielająca się ode mnie-graczki postać protagonistki: to, co w niej odmienne, zdystansowane, dookreślone i wypowiedziane.

\section{Abstract}

\section{Marta M. Kania}

INDEPENDENT SCHOLAR

The 'They'Speaks inside Me

Kania undertakes a close playing of Sunset (Tale of Tales, 2015), focusing on the relationship between the player, who perceives the avatar as herself, and the soliloquizing protagonist. Drawing on Heidegger's notions of the 'They' and 'distantiality', Kania demonstrates in what way the player's perceptual situatedness with regard to the avatar determines her aesthetic experience of the gameworld. The distantiality that emerges between the player and the protagonist becomes visible in two areas, namely when the player experiences the avatar to be a protagonist, soliloquizing and defining herself through her own gaze, and when the player experiences the avatar as the'They', with the protagonist's behaviour determining the player's position and becoming an expression of a depersonalized opinion and a form of pressure.

\section{Keywords}

game research, game studies, existentialism, philosophy of computer games, interpretation of the gameworld 